\title{
Bilingual Education in the Basque Country: Achievements and Challenges after Four Decades of Acquisition Planning [1]
}

\author{
(c) Estibaliz Amorrortu
}

University of Deusto, Bilbao

E-mail: eamorror@fil.deusto.es

\section{Basque: a minority language}

The Basque language, a pre-Indo-European isolate, is currently spoken by about 700,000 people around the South-West of the Pyrenees in the South of France and North of Spain. The Basquespeaking territory belongs, therefore, to different political and administrative entities: the Basque Autonomous Community (BAC) and the Autonomous Community of Navarre (ACN) in the Spanish State, and the Northern Basque Country,[2] in the Département de Pyrénees Atlantiques, in France.

Euskara, the Basque language, is characterized by its minority status: in contact with Spanish and French, virtually all Basque speakers are bilingual; by contrast, a majority of the population living in Basquespeaking areas speaks only Spanish or French. The minority status of Basque is also reflected in its historical absence from institutional settings such as education and the government. Only after restoration of democracy in Spain in 1978 and the creation of autonomous political institutions, were governmental language planning and policy on behalf of Basque implemented.

In contrast with other minority language situations in which speakers of the minority language are stigmatized as uneducated, rural, or holding low economic and power resources, Basque speakers do not differ from Spanish monolinguals in any of these characteristics. Even though in the past Basque was associated with lack of education, there is not such an association today. Basque speakers are now bilingual and have as much access to resources as Spanish monolingual speakers.

Two other elements contribute to the current good perception of Basque speakers: the creation of Basque institutions where the use of the minority language is promoted and the importance given to the language in a definition of Basque ethnicity.[3] Since Basque is not associated today with either a powerful or powerless group,[4] but rather with ethnic distinctiveness, and since it is being promoted in status-stressing situations, speaking it does not have negative social 
consequences. To the contrary, being bilingual (and even trilingual) is socially desirable in Basque society.

However, since the Basque-speaking territories belong to different political and administrative entities, the sociolinguistic situation of Basque and revitalization process varies considerably across regions. Although I provide some information about the situation in other Basque-speaking areas for a comparison, I focus on language planning issues in the Basque Autonomous Community because it is the area with the largest popular and governmental support and where the future of Basque is most promising. After describing the historical process of language shift, I introduce language-planning efforts to reverse it, especially in the field of acquisition planning. Although the language planning measures taken during the last decades have produced an important increase in the number of bilingual speakers, some issues, such as the level of linguistic proficiency acquired by learners of Basque, concern educators and language planners.

\section{A historical view: Geographical and social language shift}

The geographical boundaries of Basque and its social and situational distribution have changed through history. The Basque-speaking territory was once much larger than today. Toponymic research conducted by Corominas shows Basque-origin toponyms in Aragon and West Catalonia, in the mid-Pyrenees, where it is believed Basque was spoken until the $7^{\text {th }}$ century (Tovar 1959). During the $9^{\text {th }}$ and $10^{\text {th }}$ centuries, a high increase in Basque population provoked migrations to Rioja, in the south of Alava, which spread the Basque language to this area.

However, geographical language loss is attested from the Roman period, when Basque was lost in the south of Navarre. Despite Latin use in Roman urban centers, Latin influence was not very intense in the rest of the Basque Country, due to the decline of the Roman Empire. To the contrary, contact with Romance varieties was more intense and produced geographical regression of Basque from the borders inland. Basque was lost in most of Alava in the $18^{\text {th }}$ century; and by 1863 , when Prince Bonaparte drew his map of Basque dialects, Basque had been lost in west Biscay, most of Alava, south of Pamplona -this boundary is nowadays located further north-, and the Baiona area in the northern Basque Country. More recently, linguistic erosion affected the very East of Navarre.

Basque regression has not only been geographical. Social regression can be observed from the times Latin was the socially dominant language for high functions. Later, Latin was replaced by Romance 
varieties, which were used for all administrative, judicial, and political purposes. Several causes explain the progressive historical stigmatization of Basque:

1. The almost exclusive use of Romance languages in statusstressing situations,

2. The creation, from the $16^{\text {th }}$ century, of urban centers and their quick association with modernization and loss of traditional social values, which carried shift from traditional Basque to modern -more widely used- Spanish,

3. Language shift among the more powerful social groups (nobility, church, and bourgeoisie).

The local language starts to be considered primitive and inadequate for the modern times to come. Despite the apologetic support of $16^{\text {th }}$ century authors, the social prestige of Basque did not increase. To the contrary, later planning to reinforce the supremacy of Spanish during the Borbon period in the $18^{\text {th }}$ century contributed to the stigmatization of Basque since Spanish was to be the only language promoted in Spain -the only language to be used in education. The exclusive use of Spanish as the medium of instruction and subsequent punishment to children who used Basque or any other local languages in school not only made students be illiterate in their mother tongue and caused difficulties in their academic success, it also increased the association of Basque with "the language of the farmers," of the illiterate.

In addition, as a consequence of industrialization and the need of labor force during the second part of the $19^{\text {th }}$ century, a great number of Spanish-speaking immigrants outnumbered Basque speakers in many areas. Industrialization also caused a crisis in traditional values and life-style and the supremacy of Basque bourgeoisie, which traditionally had shifted to Spanish.

Immigration from other Spanish regions was especially intense in the 1940 s and 1950s during the Franco area. A significant number of monolingual immigrants moved not only to the historical industrial areas in the west of Biscay, where Basque was already lost, but also to less industrialized rural areas in Biscay and Gipuzkoa. This last flow of immigrants and the prohibition by the Franco government to use Basque produced destructive sociolinguistic regression in areas where it was the primary language. Use of Basque was restricted to the most intimate domains, especially the family, for decades until the beginning of democracy.[5] 


\section{A popular reaction to Basque language loss: the beginning of language planning}

Linguistic and cultural repression during the dictatorship period and greater consciousness of the loss of Basque distinctiveness made Basques perceive language shift as traumatic and produced a popular reaction to recover the Basque language and culture. The recovery popular movement emphasized the affective dimension of language as a symbol of belonging to the group (Tejerina 1992, 1996).

At the end of the 1950s, the Basque language became the central element in a process of change in different aspects (Tejerina 1992: 318 and ff.). Against the political and social situation of the time, Basque was perceived as the central element in a process of cultural renovation. Distinguishing from previous rural cultural manifestations, urban youngsters wanted to show their urban voice and they wanted to do it in Basque. They proved that Basque did not have to be linked only to the rural environment, that Basque was not just "the farmers' language," but rather that it could occupy an important place in the manifestation of modern urban Basque culture. The use of Euskara also distinguished the younger generations from the lack of action among the older: the younger were not only politically and socially active, they carried out their activism largely in Basque.

At the same time, the last decades of the Franco period were characterized by a rising of nationalist feelings. The Basque language took a central role in a redefinition of Basque nationalist ideology. Against previous conceptions of Basque ethnicity based on race, the language was going to be the integrative most important element of Basque distinctiveness, which produced a desire to learn L2 Basque not only among native families who had not transmitted the minority language during the dictatorship, but also among recent immigrants who wished to integrate into the host community. Considering the high number of immigrants,[6] their linguistic integration was crucial for the success of the reversing language shift measures to be taken.

However, the linguistic situation was not homogeneous across regions. At the beginning of the 1980s, Basque was spoken by only $10 \%$ of people in areas such as Metropolitan Bilbao -the most important city-, most of Alava, or industrial Encartaciones in western Biscay. But, the situation in other Biscayan areas and most of Gipuzkoa was better: Basque was spoken by 25 to $50 \%$ of the population in the San Sebastian area, for example, and more than $50 \%$ in many rural Biscayan and middle-size towns in Gipuzkoa. 
As already mentioned, a sense of loss of Basque identity parallel to the language shift process provoked a popular reaction in defense of Basque culture and language in Biscay and Gipuzkoa. The first important efforts to revitalize Basque were conducted in the 1960s in the field of acquisition planning. Schools supported with popular funds were created to teach adults Basque as a second language (gaueskolas 'night schools') and to educate children using Basque as the medium of instruction (ikastolas 'Basque schools').

The first ikastolas opened in Biscay in 1932. However, the dictatorship after the Civil War in 1936 prohibited the use of regional languages and ikastolas became ilegal. During the 1950s, a few parents and teachers opened small ikastolas in private homes, but it was not until the 1960s and 1970s that an important number of them were founded all over the Basque Country. Ikastolas at the time were private, most often cooperatives, and economically supported by the families and popular fund-raisings.

Planners engaged in the promotion of Basque had some difficulties. Apart from being a language spoken by only a minority -about one fourth of the population in the BAC, according to the 1986 census-, Basque faced other important problems for its recovery. On one hand, its speakers were illiterate in Basque. Even the most highly educated Basque speakers most frequently did not know how to write in Basque and were not accustomed to reading in this language because they were educated in Spanish or French. In addition, Basque had not been used in many status-stressing situations for a long time; modern technical registers were not developed in Basque; the literary tradition was small and mostly restricted to religious works; there was no standard variety that could be used in education and mass media; and great regional variation caused intelligibility problems among most illiterate-in-Basque speakers, who, in addition, were not used to talk to speakers of other dialects.

All these problems required corpus planning to modernize and standardize Basque, and to make available teaching materials. Textbooks that fulfilled the primary education curriculum were needed for the increasing number of students enrolled in ikastolas. In addition, the new demand of $\mathrm{L} 2$ and literacy teaching materials for adults required an important effort to language teachers. Finally, in order to face the regional variation phenomenon and lack of register variation in Basque, it was necessary to codify a standard variety and elaborate technical lexicon.

But, corpus planning was not the only difficulty that planners faced. The previous stigmatization of Basque among monolingual Spanish 
speakers, and even many bilingual speakers, had to be reversed. In order for Basque to be prestigious and for monolingual Spanish speakers to be motivated to learn it, government intervention promoted, among other, instrumental reasons, requiring individual bilingualism for certain positions in the public administration. Basque had to be declared co-official so authorities could implement measures favoring Basque. The only way to promote local languages in a situation where Spanish was the only official language was to make them co-official.

\section{Basque is declared co-official}

Governmental language planning and policy promoting Basque began after the Spanish Constitution (1978) officially recognized multilingualism in Spain. Each autonomous community has undertaken the declaration of its own regional language as official, to allow for positive discrimination measures in favor of their minority language. Differing from other kinds of official multilingualism, such as in Switzerland, regional languages are only official in the particular autonomous community and not in the entire Spanish state.

The Basque Parliament, the parliament of the BAC, declared Basque official in the Statute of Autonomy (1979) which establishes in its sixth article that

the Basque language, the language of the Basque people, shall, together with Spanish, be recognized as an official language in the Basque Country, and all the inhabitants of the Basque Country [7] will have the right to know and use both languages.

The Statute of Autonomy also establishes that Basque public (governmental) institutions will guarantee the use of both languages. However, although both Spanish and Basque are official languages in the BAC, they are not official at the same level. The Spanish Constitution establishes the right and obligation of all Spaniards to speak Spanish, whereas the Statute of Autonomy only establishes the right of Basque citizens to speak both official languages. Frequently, people who are against promotion of Basque claim that, for instance, a Basque language requirement for some civil servants is anticonstitutional, arguing that, according to the Spanish Constitution, only speaking Spanish is an obligation and, therefore, it is discriminatory to require Basque.

In 1982, the Parliament of the BAC approved the Act of Normalization of the Basque Language (Law 10/1982). This act outlines the general 
planning guidelines that will be followed by governmental institutions in the BAC to guarantee the co-official status previously granted to Basque by the Statute of Autonomy. Specifically, it establishes the creation of an Advisory Board, which is chaired by the President of the Basque Autonomous Community, of Basque Radio and Television, the regulation of the linguistic models in primary education, and the creation of the Institute for Adult Literacy and Basquization (HABE). The main goal of all these institutions is to promote the acquisition and use of Basque.

In respect to the other Basque-speaking regions, the legal situation of Basque is diverse. The Navarrese Parliament approved a Foral (Provincial) Basque Act in 1986, with the opposition of all Basque nationalist parties. This act promotes the use of Basque-language teaching and its use in the public administration exclusively in the Basque-speaking areas of Navarre (the very north) and does not give official status to Basque in the areas where it has already been lost. Recently, the Navarrese government is restricting even more their support to the minority language and, for instance, denied for the first time in 2001 annual public funds to institutions such as the Academy of the Basque Language or the Basque Studies Society.[8]

Finally, the Basque language has no official recognition in France. Although it is used in institutions such as local media, church, and some schools, there is little support from the State for Basque, nor for any other minority language in France.

\section{Language recovery through the education system}

Since Basque is spoken by only a minority, the spread of its use presents great difficulties and its future depends largely on the success of teaching it, both as a first and, especially, as a second language. Basque society expects the younger generations to guarantee Basque language maintenance and the primary education system to teach it to monolingual children and produce an increasing number of balanced bilinguals. At the same time, both governmental and non-governmental groups are also making remarkable efforts in the field of L2 Basque teaching to adults.

The beginning of acquisition planning promoting Basque faced important problems that have been solved through time. As stated before, the Basque language needed modernization and standardization; textbooks and other materials needed to be created to be used in ikastolas and euskaltegis (Basque language schools for adults); and, there were few teachers qualified to teach Basque or in Basque. Little by little, technical lexicon was codified and became 
widely used, a large amount of materials was published with both public and private funds, and teachers made a great effort to learn Basque or literacy in Basque. In fact, although only $4.6 \%$ of all public school teachers in primary and secondary education had their Basque language credentials during the 1976-77 academic year, by 1997-98, public school teachers qualified to teach Basque or in Basque were almost 70\% (Basque Government 1998).

In what follows, I introduce language planning in primary and adult education. The teaching of Basque to children and adults has clear differences in methodologies and linguistic proficiency expectations, but both contribute intensely to the increase in the number of Basque speakers produced during the last decades. Teachers, students and Basque society in general are investing significant human efforts and economical resources for the success of teaching Basque to both age groups.

\subsection{The linguistic models in primary education}

The Act of Normalization of the Basque Language (1982) officially established the use of Basque in primary education in the BAC. Following the pedagogical principle that children should be educated in their native language (Etxeberria 1999:130), four linguistic models were defined, as shown in Table 1.

\begin{tabular}{|l}
\hline \multicolumn{1}{||c||}{ LINGUISTIC MODELS } \\
MODEL A: Spanish is the language of instruction, Basque is just a \\
subject \\
MODEL B: Both Basque and Spanish are used as the medium of \\
instruction \\
MODEL D: Basque is the language of instruction, Spanish is just a \\
subject \\
MODEL X: Everything is done in Spanish, Basque is not studied at \\
all.
\end{tabular}

Table 1: Linguistic Models in the Education System in the BAC

Model $\mathrm{D}$ is the full immersion program developed by ikastolas at the end of the 1960s. Children enrolled in a Model D program take all their classes in Basque except for Spanish language and literature. The 
other two linguistic models are Model A, in which Spanish is the language of instruction and L2 Basque is taught for a few hours a week, and Model B, a bilingual program. Students living temporarily in the Basque Country can study in Model X, a program in which Basque is not taught at all. In what follows, I disregard data related to Model X because less than $1 \%$ of children study in this program in the BAC.

As stated before, the system of linguistic models was created in an attempt to answer to the linguistic plurality of the Basque Country, taking into account that children's native language may be Basque, Spanish, or both Basque and Spanish. However, it is the parents' decision in which model they want their children to be educated and a majority of families choose the Basque models ( $B$ and $D$ ), regardless of the family's native language(s).

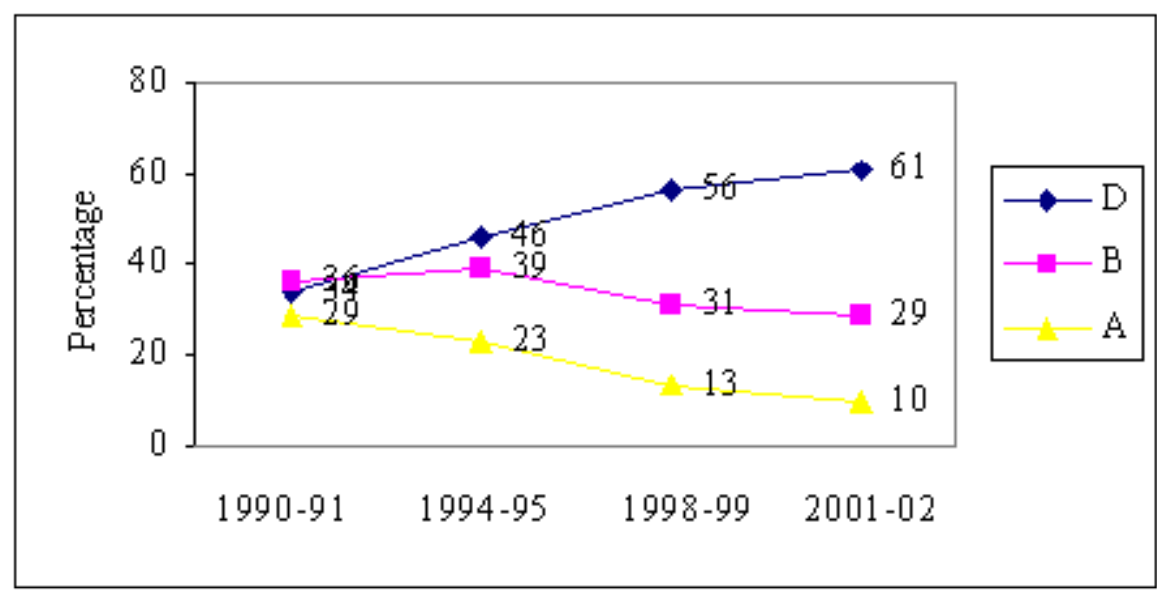

Figure 3: Enrollment in Pre-Primary[9] Education (2 to 5 year-olds) in the BAC, in each linguistic model.

(Source: Basque Institute of Statistics and Department of Education, Basque Government)

As we can observe in Figure 3, only Model D, the model where Basque is used as the medium of instruction and Spanish is taught as a subject, has increased during the last decade. Models B and, especially, A have clearly decreased, which may be surprising for some readers. Many parents do not choose the child's native language(s) as the medium of instruction. If that was the case, a great majority of students would be enrolled in the A model, considering that $58.5 \%$ of the population of the BAC is Spanish monolingual and only $24.7 \%$ is bilingual[10] (1996 census data).

The fact that, rather than full immersion in Basque, the most popular model is not the bilingual program may also surprise many. Most 
parents prefer to send their children to Basque full immersion schools because these are the ones that can better guarantee learning of Basque. Since Spanish is the majority language and it is much more used quantitatively and across a larger number of situations, even Basque monolingual children in a model D school learn Spanish without any difficulty. Whereas acquisition of Spanish is guaranteed anyway, complete acquisition of Basque is more difficult, even in full immersion or D programs.

In fact, several studies on children's linguistic proficiency in Basque and Spanish showed that Model D students have good command of both languages, whereas Model A and B students are proficient in Spanish but not in Basque (Azurmendi 1983, Etxeberria 1987, Etxeberria and Aierbe 1988, Elosua et al. 1994). Moreover, by age 12, even Model D students scored significantly better in Spanish than in Basque in a lexicon test (Azurmendi 1983, Elosua et al. 1994). Similar results are also reported for Model $D$ children and, mostly Basque native, university freshman students (Rodríguez 1995). Since Basque can be spoken by only about a third of the population and it is not used in many situations, full Basque proficiency among children living in non-Basque speaking areas is rather difficult. By contrast, the wider presence of Spanish makes it easy to learn. Many families feel that it is better for their children to use Basque in school as much as possible because Spanish can be learned easily by social interaction. Even though Model $D$ is not a bilingual program, students educated in this model are thought to be the ones most likely to be balanced bilinguals.

In respect to Navarre, the number of families who choose Basque full immersion for their children has also increased in the last decade, although at a slower rate than in the BAC. Many children will not learn Basque at all in school since they enroll in Model $X$, but this model is clearly decreasing. Figure 4 shows these tendencies. 


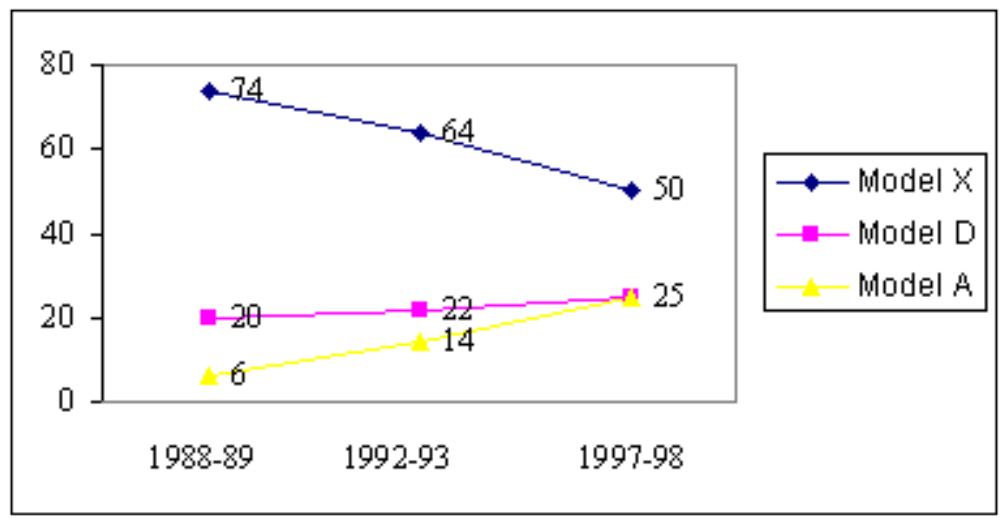

Figure 4: Percentage of Students Enrolled in Pre-Primary School Enrollment in Navarre[11]

Model $D$ is only available in the public system in the most northern area of Navarre and there is no bilingual (Model B) program in Navarrese public schools.

Finally, since the French State does not support the use of regional languages, Basque is used as the medium of instruction only in private ikastolas, where about $11 \%$ of students were enrolled in preprimary education during the 1997-98 academic year. Six percent were in a bilingual (B) program and another $6 \%$ took Basque as a subject (Etxeberria 1999:136).

To sum up, I want to highlight the clear increase in the number of children who study in a full Basque immersion program in the BAC during the last decades. This tendency shows the wide social support of Basque society to reversal language shift planning and, specifically, Basque families' trust in full immersion programs and in the school system's capacity to educate and produce bilingual students.

As stated before, the fact that the bilingual program (Model B) is not the most popular one does not mean that Basque society is not for bilingualism. It rather means that full immersion in Basque is perceived as more adequate in a bilingual situation in which there are less opportunities to use Basque.

No mention to academic achievement and its relation to the language of instruction and students' mother tongue have been made so far. The influence of the linguistic model and students' mother tongue on academic achievement has not been a general concern among either educators or researchers. Such a study would require examination of many sociolinguistic variables and independent evaluation of the Basque education system.[12] Also, the study should be longitudinal 
since the influence of the linguistic model on students' academic achievement may change in the different age groups. In the meantime, the data available does not let us believe that bilingual or immersion education causes any negative effect on students' academic achievement in the long run. A final examination given to all students who want to pursuit university studies after secondary education shows similar results among students who received primary education only in Spanish and in the Basque models, despite the fact that almost all A model students received their education in their mother tongue and many $B$ and $D$ model students received partial or total instruction in L2 Basque, respectively. Table 2 shows the percentage of students who passed exam to enter college and the mean grade they received.

\begin{tabular}{|l|l|l|}
\hline & $\begin{array}{l}\text { Passed } \\
\text { the } \\
\text { exam }\end{array}$ & $\begin{array}{l}\text { Mean } \\
\text { grade[13] }\end{array}$ \\
\hline Model A students & $67.57 \%$ & 5.86 \\
$\begin{array}{l}\text { Model B and D } \\
\text { students }\end{array}$ & $71.60 \%$ & 5.94 \\
\hline
\end{tabular}

Table 2: Results of the 'Selectividad' examination (2001) in the BAC (Source: Department of Education, Basque Government, personal communication)

Since full immersion in Basque does not bring along an academic burden on children coming from Spanish-speaking families, and since full competence of Spanish is ensured even in full immersion in Basque programs, parents prefer to reinforce the presence of Basque in the education of their children.

\subsection{Teaching Basque to Adults}

The field of Basque language teaching to adults entails both $L 2$ teaching (Euskalduntze 'Basquization') and literacy teaching (Alfabetatze 'Literarization'). At the same time that ikastolas started to be founded, and as part of the grass-root movement for the recovery of Basque language and culture reported in section 3, in 1965, the Academy of the Basque language began to teach Basque speakers how to write their mother language. Since Basque was not used in education and it was banned from the media, Basque speakers were literate only in Spanish or French. As the recovery movement became stronger, many monolinguals required L2 Basque language classes as 
well, which required a big effort to create materials adequate for the new needs.

In 1979, a private association called Alfabetatze eta Euskalduntze Koordinakundea (AEK) was created with the objective of working on the revitalization process by teaching literacy and L2 Basque, creating teaching materials, forming Basque language teachers, and working on language-loss consciousness raising. AEK uses a functionalist and communicative approach to language teaching, based on independent teaching of the four linguistic skills (AEK2001). Today, about one hundred schools and six hundred teachers are part of this teaching institution.

HABE -a governmental institution that was going to fulfill the same functions that AEK was already serving- was born in 1983 within the Basque government. The main objectives of HABE are to prepare Basque language teachers, create teaching materials, and decide the curriculum in the literacy and basquization processes. The two institutions work in harmony after going through some previous difficulties. Currently, HABE focuses on the creation of new teaching materials and the continuous formation of teachers, whereas AEK and other schools pursue the actual L2 Basque teaching, which involves about 120 schools and almost 40,000 students a year (HABE: 2002).

\section{Results of education policies: achievements and challenges}

After four decades of language planning to promote Basque in the BAC, we can observe some results, but also some challenges for the future. In this section, I review some of the changes produced in the revitalization of Basque and I point to some of the difficulties that are arising.

There is no doubt that the situation of Basque is better now than a few decades ago. There is an increasing number of bilingual speakers, especially among the younger generations and due mostly to the introduction of Basque in the education system. Although educators and scholars are concerned about the proficiency level acquired in Basque and the high degree of Spanish and French interference among young speakers -I will refer to this issue later-, the fact that most children are (or are in the process of being) bilingual is positive and must be underlined. The effect of the promotion of Basque in the education system is clear when looking at language competence data across age groups. Figure 5 shows language competence in the $\mathrm{BAC}[14]$ across age groups, according to the last census data available. 


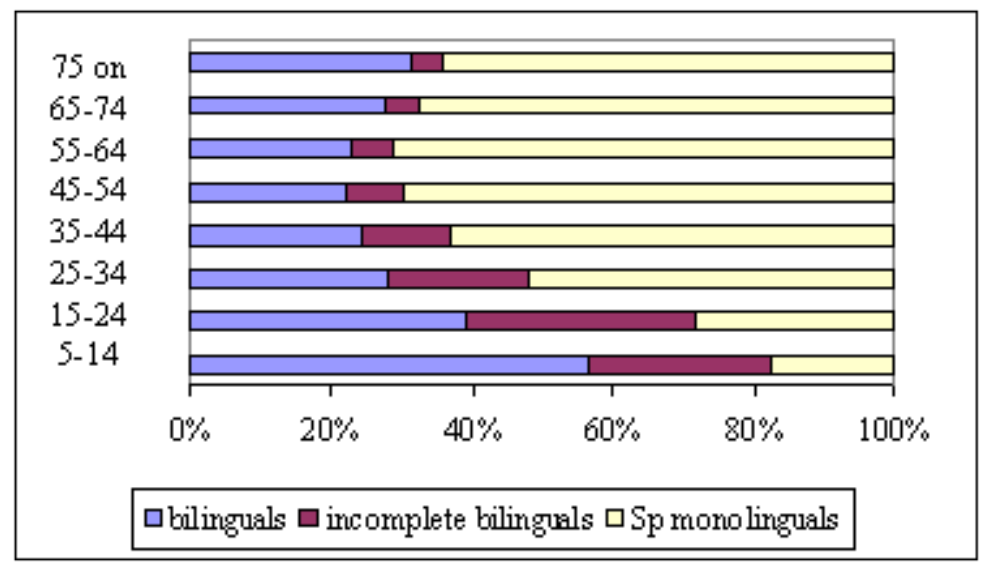

Figure 5: Language competence in the BAC across age groups (1996 Census data)

The more monolingual age group is the one of those who were 45 to 64 year-old in 1996. This group is formed by two groups of people. On one hand, Basques who were raised after the civil war, when Basque was prohibited. At the time, many did not transmit the local language within the family due to social and political pressure. On the other, Spanish immigrants who moved to the Basque Country during the 1940s and 1950s did not have the need to integrate linguistically in the hosting community. The former group experienced significant language loss and the latter did not take part in the language recovery movement.

To the contrary, many in the younger generations learned L2 Basque as adults or in immersion or bilingual programs in primary education. The high and increasing percentage of bilingual speakers in the younger generations is directly related to promotion of Basque in education and, to a less degree, to familial transmission of Basque by non-natives.

But acquisition planning, even though the most important, is not the only cause of the increasing tendency towards bilingualism in the Basque Country. There is no doubt that the status of Basque is better now. Two causes explain the better prestige of Basque: it is now used in more domains, especially in status-stressing situations, and it is promoted for instrumental reasons without loosing the affective, integrative element that was always present in the Basque-speaking community.Basque is now used in situations in which it was never used: books on all topics are published in Basque; dissertations are written on the most specialized areas of knowledge; Basque can be 
used in almost all areas of the public administration;[15] all kinds of mass-media are produced in Basque.

The other important reason why the prestige of the minority language has increased and continues to increase is that it is promoted for instrumental reasons. Since the Basque-speaking community is not a group of otherwise homogeneous social characteristics, there is no identification of Basque speakers with a powerful or powerless group. But Basque is required for some jobs in the public administration and Basque society perceives that far from being harmful, being bilingual is for someone's advantage. Although all learners of Basque had integrative motivations at the beginning of the recovery movement in the 1960s and 1970s, instrumental reasons have reinforced integrative ones lately.

A review of reversal language shift planning during the last decades also points to some challenges for the future. I will comment on two interrelated issues: minority language use and acquisition of full communicative competence. The minority situation of Basque is clearly shown by its low use in informal encounters. Even though the number of Basque speakers (knowledge) has increased, Basque use is still more reduced than desired. Basque language use in informal encounters in big towns and cities has only increased substantively in Gipuzkoa (Altuna 1998), the province with the highest number of bilingual speakers. Seventeen point two percent of informal interactions measured in urban Gipuzkoa in 1989 were conducted in Basque, whereas the percentage increases to 19.65 in 1993, and 22.91 in 1997. However, no substantive change has been observed in the other provinces.

The tendency to shift to the majority language in informal situations is caused by the high density of monolingual speakers in urban centers and the lack of full communicative competence among many speakers. In fact, one of the major current concerns among language planners and educators is language proficiency: the "quality" issue. Teachers and scholars constantly report inadequate Basque language proficiency, which is manifested in the use of artificial language, transfer from Spanish or French, constant code-switching, and divergence from older speakers' Basque.

The use of Batua (the newly codified unified variety), which is the variety mainly used in education, is still sometimes associated with artificiality in opposition to the use of regional dialects, which are considered more authentic (Amorrortu 2000). The fact that Batua is used as a second variety by all speakers makes many associate it with non-native speech (euskaldunberrien euskera 'non-natives' 
Basque') and even with low proficiency. Proficiency in the Basque (Batua by default) of non-native children in immersion programs is a major concern.

Consequently, we can say that the biggest difficulty that language teachers and educators face in the process of teaching Basque to Spanish monolingual students relies on teaching communicative competence -appropriate language use in different situations- in highly monolingual areas. At the beginning of the language recovery movement, most children studying in ikastolas came from Basquespeaking families, and ikastolas just attempted to educate them in their native language, despite all obvious difficulties involved in literacy teaching. It was enough to teach literacy skills -the use of elaborate registers- in Basque, since children acquired informal and intimate registers at home.

Shortly, assuming that their children would learn Basque as a second language easily in school, an increasing number of monolingual Spanish-speaking families also enrolled their children in ikastolas. Full immersion Basque learners easily acquire the written, more formal registers associated with the acquisition of literacy. However, unless they are involved in Basque-speaking networks, they hardly learn any register appropriateness and tend to either overuse the school 'formal' register in informal situations, risking being perceived as artificial, or shift to Spanish to avoid register inappropriateness.[16]

The mentioned problems lead us to point to some important issues for the future. First of all, in order to increase the use of Basque among natives and non-natives, Basque planners need to promote integrative as well as instrumental reasons, since the former are more likely to ensure language use.[17] Second, measures promoting Basque still need to be taken in many areas in governmental and private institutions to ensure bilingual language use. Although the situation of Basque is better now than a few decades ago, there is still a long way to go before getting into a situation of balanced social bilingualism. The more situations available for Basque speakers the fuller communicative competence they will acquire. Finally, the teaching field needs to continue teaching students full communicative competence, creating a wide range of situations of use so their students become proficient speakers not only in elaborated registers, but also in the more colloquial and intimate ones.

\section{Last remarks: from the Basque Country to New Jersey}

The Basque case is often described as a success, given the remarkable increase in the number of bilingual speakers in the 
younger generations and the wider presence of Basque in statusstressing situations. As stated before, two reasons explain this social change: a positive popular attitude toward the planning measures to be implemented and economical resources and governmental support. A big grass-root movement started the consciousness-raising movement for the recovery of Basque language and culture, and government intervention provided the legal and economical resources needed to implement reversing language shift measures. Any kind of language planning needs both aspects to be successful.

In what respects acquisition planning specifically, the efficiency of bilingual programs is often evaluated by politicians without taking into account that, if bilingual programs will be beneficial for minority students, the community has to have a positive attitude towards the measures, and education authorities need to provide with the resources needed to create quality bilingual programs. There is no way to develop good bilingual programs without the economical resources needed and without the support of teachers, families and society in general. If the Basque case can show anything, it can show that social, political, and economical support are all necessary for the success of language planning.

However, many of the measures taken in the Basque case may not be adequate, desirable, or even possible in other situations. We need to take into account the different cases before transferring any measures. For example, the fact that full immersion in Basque is considered to be the best by Basque parents should not take us to believe that full Spanish immersion would be the best program for Spanish-speaking students in the US, because neither the situation of the minority language in each country, or the social consequences of speaking each language are the same. Or, to give another example, the fact that the officialization of Basque made possible the implementation of measures to favor it should not encourage anybody to think that minority languages should gain official status in the US, especially given that there is no official language in most American states.

What may be transferable from the Basque case is the idea of support for diversity and promotion of the weaker with positive discrimination, a political measure that is needed in an unbalanced situation. If we want a fair and more tolerant society, we need to promote diversity (multilingualism and multiculturalism), and the only way to assist minorities and protect their existence is by doing positive discrimination. 
Finally, sociolinguists, language planners, and educators should be able to convince our societies of the social, cultural, and even economical advantages of multilingualism, and the new possibilities that cultures in contact offer. Belonging to two linguistic communities, integrating into new ones without giving up our own, is not only possible but also more and more desirable in the global world.

\section{References}

AEK web site (2002): http://www.aeknet.net

Altuna, Olatz (1998). Euskararen kale erabilpena Euskal Herrian. Bat Soziolinguistika Aldizkaria 28:15-64.

Amorrortu, Estibaliz (2000). Linguistic Attitudes in the Basque Country: the Social Acceptance of a New Variety. Unpublished dissertation: University of Southern California.

Azurmendi, M. Jose (1983) Algunos aspectos del euskara utilizado hoy. Iker 2:175-187.

Basque Government web site (1998), Department of Education, Universities and Research:

http://www.euskadi.net/entesinstitucionales/hezkuntza/indice_i.htm

Basque Government, Navarrese Government, and Instituto Cultural Vasco (1996). La continuidad del euskara. Encuesta Sociolingüística de Euskal Herria. Vitoria-Gasteiz: Basque Government and Navarrese Government Press.

Elosua, Pauli; López, Alicia; \& Artamendi, Juan Angel (1994). Elebiduntasunari buruzko testaren bidez lortutiko datuen azterketa kuantitatiboa. Tantak 12:197-217.

Etxeberria, F. \& Aierbe, P. (1988). Eskolako Euskal Elebitasunaren Ikerketa . II Euskal Mundu-Biltzarra. Euskara Biltzarra 2:130-135.

Etxeberria, Feli (1987). El fracaso de la escuela. San Sebastian: Erein.

Etxeberria, Felix (1999). Bilingüismo y Educación en el País del Euskara. San Sebastian: Erein. 
Fishman, Joshua A. (1991). Reversing Language Shift. Theoretical and Empirical Foundations of Assistance to Threatened Languages. Clevedon: Multilingual Matters.

HABE web site (2002): http://www.habe.org

Rodríguez, Fito (1995). Elebitasuna eta Elebiduntasuna: Euskal Herriari buruzko azterketa soziolinguistikoa eta ondorio psikopedagogikoak. Ele 16:75-91.

Tejerina, Benjamín (1992). Nacionalismo y lengua. Madrid: Centro de Investigaciones Sociológicas.

--- (1996). Language and Basque Nationalism: Collective Identity, Social Conflict and Institutionalisation. In C. Mar-Molinero and A. Smith (eds.), Nationalism and the Nation in the Iberian Peninsula. Competing and Conflicting Identities. Oxford: Berg.

Tovar, Antonio (1959). El euskera y sus parientes, Madrid: Ediciones Minotauro.

Zuazo, K. (1995). The Basque Country and the Basque language: An overview of the external history of the Basque language. In Hualde, J. I., Lakarra, J. A., and Trask, R. L. (eds.) Towards a History of the Basque Language. Amsterdam: John Benjamins Publishing Company. Pp. 5-30.

\section{More information about language planning in the Basque Country}

Center of Basque Studies, University of Nevada, Reno (UNR) -http://basque.unr.edu

Basque library at UNR -- http://catalog.library.unr.edu

Deputy Ministry for Language Policy, Basque Government -http://www.euskadi.net/euskara/indicei_i.htm

Department of Education, Universities and Research, Basque Government --

http://www.euskadi.net/entesinstitucionales/hezkuntza/indice_i.htm 
Language Planning Department, Navarrese Government (not available any more) -http://www.cfnavarra.es/euskera/euskera/eprinci.htm

Basque Institute of Statistics -- http://www.eustat.es

HABE, Institute for L2 and L1 Basque Language Teaching, Basque Government -- http://www.habe.org

AEK, Association for L2 and L1 Basque Language Teaching -http://www.aeknet.net

Association of Ikastolas -- http://www.ikastola.net/default.html [Wayback Machine]

\section{Notes}

1 I would like to thank José Camacho, Liliana Sánchez, and Tom Stephens for their invitation to participate in the 'Bilingualism and Bilingual Education' Workshop and hospitality during my stay in New Jersey. I also want to express my gratitude to all the participants of the Workshop for their comments and questions.

2 Unless otherwise stated, the term Basque Country will be used to refer to the three regions.

3 Basque is also sometimes associated with Basque nationalism, which entails great social adherence to the minority language by an important part of Basque society.

4 Even Basque intra-language variation is not associated with social groups. The Basque variety used for standard purposes is not a variety associated with a group of otherwise homogeneous social characteristics; unlike in other western societies, speakers of the Basque standard variety are not characterized by more education or greater social prestige, since the standard is a unified variety recently codified by the Academy, and not the variety of the more powerful (yet).

5 See Zuazo (1995) for more details on the social history of Basque. 
6 According to the 1986 census, $35 \%$ of the population in the BAC was immigrant and $20.4 \%$ was born in the BAC from immigrant parents.

7 Basque Country in this quotation refers to the BAC.

8 The government of the Navarrese Foral Community also decided to close down the Language Planning Department. The internet-site referred to in the References section at the end of the article is not on line anymore. The change in governmental politics regarding the use of Basque in official settings is due to a change in the political party responsible for governing in Navarre.

9 I provide enrollment data in pre-primary education because it reflects parents' latest reaction to the possibilities that the education system provides. Students usually continue in the same linguistic model through all primary education.

10 The rest are semi-speakers in the minority language. The 'semispeaker,' 'incomplete speaker,' or 'passive bilingual' categories have been applied to people who do know some Basque, but are not able to speak it fluently. The range in the linguistic proficiency of semispeakers is very wide.

11 Data provided by the Department of Education and Culture of the Navarrese Government, quoted from Etxeberria (1999:135). The decision of the Navarrese Government not to promote the Basque language clearly differs from the increasing demand by parents of Basque classes (in Model A) and instruction in Basque (Model D) for their children, as shown by recent enrollment figures in pre-primary education.

12 Education authorities also need to examine the specific needs of recent immigrant students and whether the linguistic models currently offered are appropriate for this increasing and linguistically heterogeneous group.

13 The maximum grade is 10 and a grade of 5 is needed to pass the exam.

14 The situation in Navarre and Northern Basque Country is different. The percentage of bilingual speakers in Navarre is very similar (around 10\%) in all age groups, although among the younger generations there is a higher percentage of incomplete Basque speakers (around $25 \%$ of people between 16 and 45 ).

On the other hand, Basque seems to be disappearing in France: the 
younger an age group the fewer bilingual and Basque semi-speakers. Almost $40 \%$ of people 65 or older spoke Basque, according to a study conducted in 1996, whereas only $10 \%$ of 16 to 24 year-old youngsters could speak it (Basque Government et al. 1996).

15 This does not mean that Basque is actually used in all areas. The judicial and public health systems are still the areas in which Basque is less used. In fact, most business is still conducted in Spanish.

16 See Amorrortu (2000) for further details.

17 Fishman criticized governmental language planning because it promoted the status of Basque in the educational system, mass media, and the government -areas in which government intervention is possible- and did not pay enough attention to familial transmission (1991: 158-182). 